\title{
Abnormal xiphosurids, with possible application to Cambrian trilobites
}

\author{
Russell D.C. Bicknell, Stephen Pates, and Mark L. Botton
}

\begin{abstract}
Xiphosurida comprise an archetypal arthropod group of considerable interest to both biological and palaeontological researchers. This appeal is generated by a combination of unique anatomical features, utility as modern analogues for extinct arthropod groups, and an impressive fossil record. Although xiphosurids have been extensively studied, there are few published examples of abnormal specimens. Abnormalities in xiphosurids have mostly been attributed to injuries (either self-inflicted, from mating, or predation) or teratologies (developmental and genetic malfunctions). Here we summarise all previously recorded extant xiphosurid abnormalities and describe new examples of injuries and teratologies to Limulus polyphemus and Tachypleus tridentatus. Furthermore, we present the first evidence of injured fossil xiphosurids: Euproops danae and Mesolimulus walchi. We identify two main groups of telson teratologies and document new ' $U$ ' shaped cephalothoracic injuries to the anterior cephalothoracic margins of $L$. polyphemus and T. tridentatus. We show ' $V$ ' and 'W' shaped injuries to $E$. danae and $M$. walchi cephalothoracic sections. A further specimen of $E$. danae is described, which likely represents plastic deformation of a recently moulted exoskeleton, rather than an abnormality sensu stricto. We compare injuries on extant xiphosurids to extinct Cambrian trilobite injuries to suggest that rare cephalic injuries to trilobites were incurred during soft-shelled exoskeletal stages. Reviewing xiphosurid injuries through time is a pivotal step towards understanding how Recent and extinct arthropods responded to injuries.
\end{abstract}

Russell D.C. Bicknell. Palaeoscience Research Centre, School of Environmental and Rural Science, University of New England, Armidale, New South Wales, 2351, Australia. rdcbicknell@gmail.com Stephen Pates. Department of Zoology, University of Oxford, Oxford, OX1 3PS, United Kingdom. stephen.pates@zoo.ox.ac.uk and Institute of Earth Sciences, University of Lausanne, Lausanne, CH1015, Switzerland.

Mark L. Botton. Department of Natural Sciences, Fordham University, New York, NY 10023, USA. botton@fordham.edu 
Keywords: injuries; Xiphosurida; Limulus polyphemus; Tachypleus tridentatus; Euproops danae; Mesolimulus walchi

Submission: 3 March 2018 Acceptance: 29 May 2018

\section{INTRODUCTION}

Xiphosurids have been studied extensively due to the unique biological and palaeontological features of the clade. The Atlantic horseshoe crab, Limulus polyphemus (Linnaeus, 1758), is the best documented extant xiphosurid, and has been the subject of detailed anatomical (Owen, 1872; Lankester, 1881; Shultz, 2001; Battelle, 2006; Bicknell et al., 2018a), biochemical (Kaplan et al., 1977), physiological (Sokoloff, 1978) and population dynamic (e.g., Botton, 1984; Brockmann, 1990; Schaller et al., 2005; Gerhart, 2007) investigations since the 1800s (van der Hoeven, 1838; Walls et al., 2002). Palaeontologists have studied xiphosurids for multiple reasons, including a fossil record that extends as far back as the lower Ordovician, 480 million years ago (Babcock et al., 2000; Van Roy et al., 2010; Briggs et al., 2012; Lamsdell, 2013; Bicknell et al., 2018a, b). Furthermore, paleontologists have been intrigued by the morphological similarities of $L$. polyphemus and fossil xiphosurids like Yunnanolimulus luopingensis Zhang et al., 2009 (Guanling Formation, China, Triassic; Hu et al., 2017), Mesolimulus walchi (Desmarest, 1822) (Solnhofen Limestone, Germany, Jurassic; Sekiguchi and Sugita, 1980; Smith and Berkson, 2005) and Limulus darwini Kin and Błażejowski, 2014 (Sławno Limestone, Kcynia Formation, Poland, Late Jurassic; Błażejowski, 2015). Finally, L. polyphemus is a useful modern analogue for exploring how extinct gnathobase-bearing arthropods consumed food, including large eurypterids (Selden, 1981; Poschmann et al., 2016), Sidneyia inexpectans Walcott, 1911 (Zacaï et al., 2016; Bicknell et al., 2018b; Bicknell and Paterson, 2018), and Alacaris mirabilis Yang et al. 2018.

Abnormalities to extinct and extant xiphosurids are poorly documented despite the extensive research into the group. Those abnormalities to extant xiphosurids that have been documented are mostly telson teratologies (Table 1) (Shuster Jr, 1982, 2009; Botton and Loveland, 1989; Shuster Jr and Sekiguchi, 2004). Injuries to female opisthosomal sections and cephalothoracic appendages have been documented and are records of injuries incurred during mating, burrowing, or other activi- ties (Brockmann, 1990; Schaller et al., 2004, 2005; Duffy et al., 2006; Shuster Jr, 2009). There is also one documented example of Limulus polyphemus with a substantially buckled cephalothoracic margin (Jell, 1989). No explicit evidence of abnormal extinct xiphosurids has been documented to date, although possible predatory drag-marks are known from the Karlstadt Formation, Germany (Middle Triassic) (Diedrich, 2011). The general lack of documented abnormalities suggests that either they are rare in extant and extinct xiphosurids [sensu Packard (1870) and Bateson (1894)] or that abnormalities are simply not noted. Here, following Gudger (1935), the second option is supported: extant and extinct xiphosurid abnormalities are undocumented, except in extreme cases. We suggest that documenting new abnormalities may extend our knowledge of recovery patterns (Shuster Jr, 1982) and help elucidate how extinct euarthropods, such as trilobites, recuperated from injuries (Bang and Bang, 1982).

Specimens of Limulus polyphemus and Tachypleus tridentatus (Leach, 1819) with abnormalities are illustrated here to document new examples thereof. Note that only juvenile and adult specimens with abnormalities are presented, as extensive research on developmental embryonic abnormalities has previously been conducted (e.g., Itow, 1985, 1986; Itow et al., 1998b). Injured specimens of Euproops danae (Meek and Worthen, 1865) (Francis Creek Shale, Upper Carboniferous), and Mesolimulus walchi (Solnhofen Limestone, Jurassic) are documented to show fossil xiphosurid injuries. The possible causes and implications of these injuries are considered. Finally, injuries to xiphosurid cephalothoraces are compared to those affecting selected Cambrian trilobites to explore the possible timing of the injuries (Babcock, 1993; Pates et al., 2017).

\section{Abnormalities defined}

To clarify the terminology used here, we highlight the three major types of abnormalities: injuries (predatory, self-inflicted and through mating), teratologies (genetic and developmental causes) and pathologies (the result of disease or parasites) (Owen, 1985). Although applied originally to trilobites, these same terms are applied here to xipho- 
TABLE 1. Summary of documented Recent xiphosurids with abnormalities.

\begin{tabular}{|c|c|c|c|}
\hline $\begin{array}{l}\text { Reference and figure number } \\
\text { (where given) }\end{array}$ & Abnormality & Species & Possible Cause \\
\hline $\begin{array}{l}\text { Packard (1870, figure } 36) \text {. } \\
\text { Refigured in Bateson (1894, } \\
\text { figure 143), and Gudger (1935, } \\
\text { no figure number) }\end{array}$ & $\begin{array}{l}\text { Forked telson bifurcating at the last } \\
\text { third of the sagittal length }\end{array}$ & Limulus polyphemus & Not stated \\
\hline $\begin{array}{l}\text { Osburn (1911, no figure number). } \\
\text { Refigured in Gudger (1935, no } \\
\text { figure number) }\end{array}$ & $\begin{array}{l}\text { Double telson bifurcating at } \\
\text { opisthosomal joint }\end{array}$ & Limulus polyphemus & Moulting \\
\hline Gravier (1930, figure 1) & $\begin{array}{l}\text { Forked telson bifurcating halfway } \\
\text { sagittal length }\end{array}$ & Tachypleus sp. & $\begin{array}{l}\text { Mechanical damaged during } \\
\text { early development }\end{array}$ \\
\hline Gudger (1935, no figure number) & $\begin{array}{l}\text { Forked telson bifurcating in the last } \\
\text { fifth of the sagittal length }\end{array}$ & Limulus polyphemus & Moulting \\
\hline $\begin{array}{l}\text { van der Meer Mohr (1935, figures } \\
2-4)\end{array}$ & $\begin{array}{l}\text { Shortened processes, pretarsus and } \\
\text { apotele of pushing legs }\end{array}$ & $\begin{array}{l}\text { Tachypleus gigas } \\
\text { (Müller, 1785) }\end{array}$ & Not stated \\
\hline $\begin{array}{l}\text { van der Meer Mohr (1935, figure } \\
\text { 1) }\end{array}$ & $\begin{array}{l}\text { Slit-like injury to posterior } \\
\text { cephalothorax }\end{array}$ & Tachypleus gigas & Not stated \\
\hline $\begin{array}{l}\text { van der Meer Mohr (1941) (not } \\
\text { figured) }\end{array}$ & $\begin{array}{l}\text { Shortened processes, pretarsus and } \\
\text { apotele of pushing legs }\end{array}$ & Tachypleus gigas & Predation or mating \\
\hline $\begin{array}{l}\text { van der Meer Mohr (1941) (not } \\
\text { figured) }\end{array}$ & Curved telson & Tachypleus gigas & Predation or mating \\
\hline $\begin{array}{l}\text { van der Meer Mohr (1941) (not } \\
\text { figured) }\end{array}$ & $\begin{array}{l}\text { Removal and recovery of moveable } \\
\text { spines }\end{array}$ & Tachypleus gigas & Predation or mating \\
\hline Bursey (1977) (not figured) & $\begin{array}{l}\text { Amputated legs (specific leg not } \\
\text { stated) with thickened endocuticle }\end{array}$ & Limulus polyphemus & Not stated \\
\hline Shuster Jr (1982, figure 14. A) & $\begin{array}{l}\text { Double telson bifurcating at the } \\
\text { opisthosomal joint }\end{array}$ & Limulus polyphemus & Mechanical injury \\
\hline $\begin{array}{l}\text { Shuster Jr (1982, figure 14. B- } \\
\text { D) }\end{array}$ & $\begin{array}{l}\text { Forked telsons. } B \text { and } C \text { bifurcate } \\
\text { halfway along the sagittal length. } D \\
\text { bifurcates at the distal section }\end{array}$ & Limulus polyphemus & Mechanical injury \\
\hline Shuster Jr (1982, figure 14. E) & Enlarged axial spine & Limulus polyphemus & Mechanical injury \\
\hline Shuster Jr (1982, figure 14. F) & $\begin{array}{l}\text { Kink halfway along the telson with } \\
\text { enlarged axial spine }\end{array}$ & Limulus polyphemus & Mechanical injury \\
\hline $\begin{array}{l}\text { Botton and Loveland (1989) (not } \\
\text { figured) }\end{array}$ & $\begin{array}{l}\text { Injured book gills, missing or short } \\
\text { telsons }\end{array}$ & Limulus polyphemus & $\begin{array}{l}\text { Predation by gulls, mechanical } \\
\text { injury }\end{array}$ \\
\hline Jell (1989, figure 1) & $\begin{array}{l}\text { Left anterior cephalothoracic margin } \\
\text { buckled. Left opisthosomal section } \\
\text { with two fewer moveable spines than } \\
\text { the right }\end{array}$ & Limulus polyphemus & $\begin{array}{l}\text { Mechanical deformation post- } \\
\text { moult. Rocks or waves }\end{array}$ \\
\hline Brockmann (1990, figure 3) & $\begin{array}{l}\text { Injured female posterior } \\
\text { opisthosoma }\end{array}$ & Limulus polyphemus & Injuries from mating \\
\hline $\begin{array}{l}\text { Schaller et al. (2004) and } \\
\text { Schaller et al. (2005) (not figured) }\end{array}$ & Loss of male pedipalp & Limulus polyphemus & Injuries from mating \\
\hline Schaller et al. (2004) (not figured) & $\begin{array}{l}\text { Hole through the dorsal } \\
\text { cephalothoracic section }\end{array}$ & Limulus polyphemus & Predation by gulls \\
\hline Duffy et al. (2006) (not figured) & $\begin{array}{l}\text { Decayed lateral eyes, missing or } \\
\text { damaged prosomal appendages }\end{array}$ & Limulus polyphemus & $\begin{array}{l}\text { Disease, ageing, mechanical } \\
\text { injury }\end{array}$ \\
\hline Shuster Jr (2009, figure 1) & $\begin{array}{l}\text { Butterfly spawning scars on female } \\
\text { opisthosoma }\end{array}$ & Limulus polyphemus & Injuries from mating \\
\hline
\end{tabular}


surids. The cause of an abnormality cannot always be determined with complete certainty. This is especially the case for smaller examples, or injuries that have undergone many stages of recovery and therefore do not reflect the original, potentially diagnostic, shape.

Injuries. Unsuccessful predation, complications during burrowing, mating or moulting can produce injuries. Injuries are identified by cicatrisation (healing through scar formation), repair and/or substantial exoskeletal deformity. Mechanical damage (predation, burrowing, mating) produces ' $\mathrm{V}$ ', 'W', or ' $L$ ' shapes, while injuries incurred during moulting are more often ' $U$ ' shaped, indicating a tearing of the soft-shelled exoskeleton. Injuries may undergo partial regeneration during subsequent ecdysial events. This partial regeneration can change the injury shape from ' $V$ ', ' $W$ ' or ' $L$ ' shapes to ' $U$ ' shapes, obscuring the distinction between the mechanical or moulting injuries.

Teratologies. Genetic or developmental malfunctions result in the growth of additional or unusual spines, and missing or additional segments, without evidence for cicatrisation or healing. Additional spines have also been reported from the location of a healed injury in trilobites (e.g., Pates et al., 2017, figure 4) blurring the distinction between teratologies and injuries.

Pathologies. Disease causes locally expressed atrophy and parasites force abnormal growth around the infested exoskeleton. The shape of the growth can diagnose parasites. Leibovitz and Lewbart (2003) should be considered for examples of xiphosurid pathologies, as the focuses here are injuries and teratologies.

\section{METHODS}

Two Limulus polyphemus specimens with injured cephalothoracic margins were collected from the Great Bay area, New Hampshire. These specimens were photographed with a Canon PowerShot SX60 HS. Additional live adult specimens with abnormalities were photographed by M. L. Botton using a Pentax K camera, during the 19801990 field seasons in Delaware Bay, New Jersey. The live juvenile specimen was photographed by M. L. Botton with a Fujifilm Finepix camera during the 2015 field season in Jamaica Bay, New York. The specimens from Great Bay, Delaware Bay and Jamaica Bay were not accessioned into collections as they were originally documented as points of interest, not the focus of a specific study. The collections of extant xiphosurids in the Zoological Collection of the Oxford Museum of Natural History
(OUMNH.ZC), and palaeontological collections of the Museum of Comparative Zoology (MCZ), Harvard, Field Museum (FMNH), Chicago and Royal Ontario Museum Invertebrate Palaeontology (ROMIP), Toronto, were examined for abnormalities. These fossil specimens were photographed with a Canon 500D Digital SLR camera and macro lens controlled for remote shooting with EOS Utility 2 or with a Canon PowerShot SX60 HS. Injured trilobite specimens from the South Australian Museum (SAM), Adelaide and National Museum of Natural History (USNM), Washington, DC were photographed with a Canon EOS 5D digital camera with a Canon MP-E $65 \mathrm{~mm}$ 1-5x macro lens and Canon EOS 6D Mark II, respectively.

\section{RESULTS}

\section{Abnormal extant taxa}

Telson teratologies. The most often reported Limulus polyphemus abnormalities are to the telson: $5 \%$ of males and $3 \%$ of females in the Delaware Bay spawning population have abnormal telsons (Botton and Loveland, 1989). Excluding short or missing telsons, two types of potential teratologies are described here: (1) forked telsons (the most often observed teratologies) and (2) double telsons (Table 1). These teratologies range between symmetrically bifurcated telsons, as noted by Gudger (1935), to asymmetrical (Figure 1.2, 1.4). The forked telson is characterised by a telson bifurcation at least half way along the spine (Schuster Jr, 1982; Figure 1.2; Table 1). The forked telson can also result in an overdeveloped axial spine (Figure 1.4). Double telsons have full-length telson spines that bifurcate at the opisthosomal base (Gudger, 1935, Figure 1.1, 1.3). Other telson teratologies include the extension of the posterior opisthosoma parallel with a damaged telson (Figure 1.5) and telson spines that curve in side-on view (van der Meer Mohr, 1941).

Cephalothoracic abnormalities. Injuries along the Limulus polyphemus cephalothoracic margin are rarer than telson teratologies. The cephalothoracic injuries consist of at least one ' $U$ ' shaped embayment in the dorsal margin, with rare examples of multiple embayments (Figure 2.1-7). One extreme cephalothoracic injury to the Tachypleus tridentatus specimen was noted (OUMNH.ZC.25121): a large ' $U$ ' shaped injury to the right cephalothorax producing a sharply buckled border (Figure 3.1-5). This specimen is similar to the L. polyphemus specimen in Jell (1989, figure 1). However, the Jell (1989) specimen has buckling 
PALAEO-ELECTRONICA.ORG

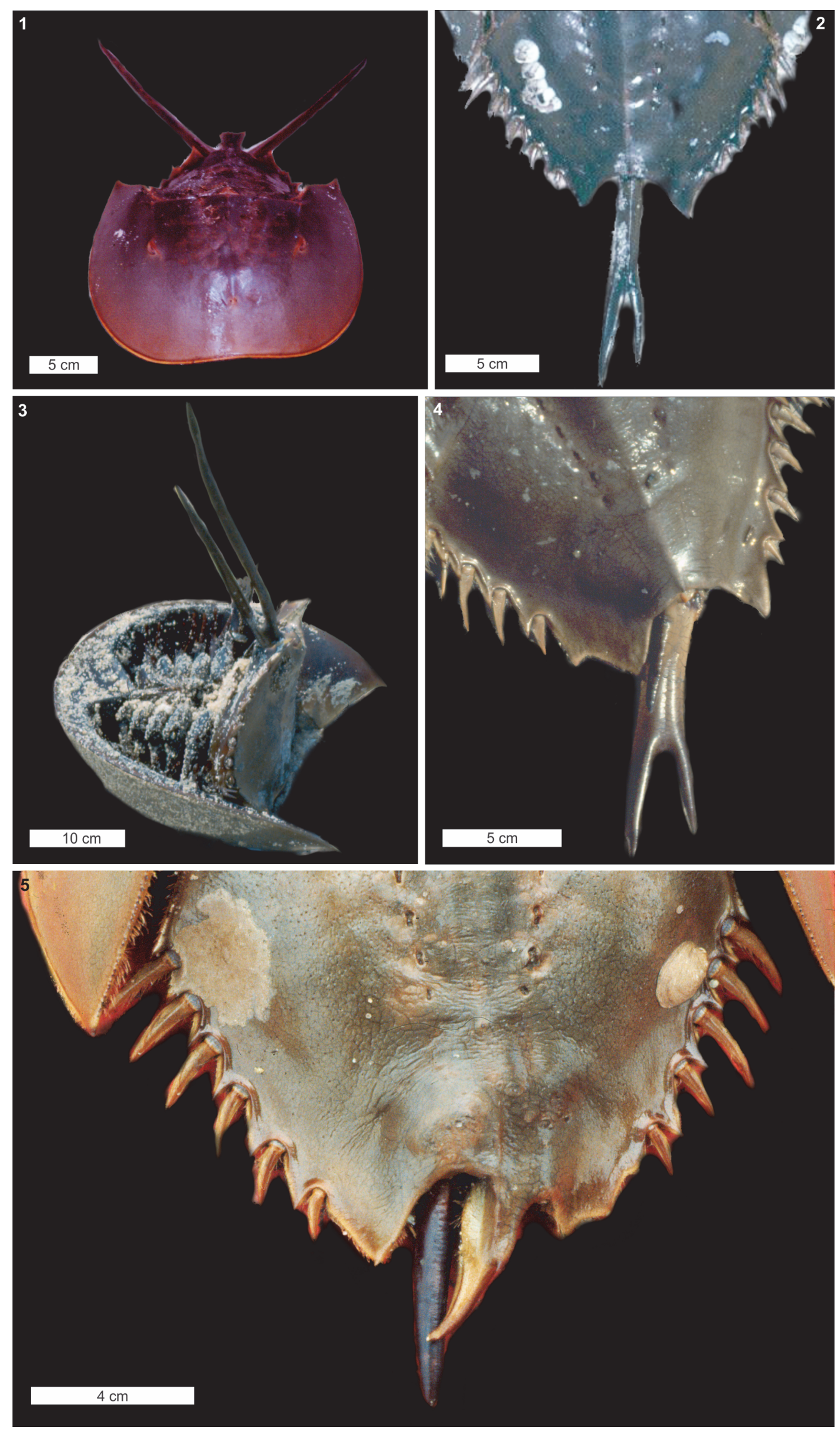


that forced the cephalothoracic margin to extend out laterally from the original margin, a feature not noted here. Other cephalothoracic abnormalities include a slit-like embayment to the left posterior cephalothorax (van der Meer Mohr, 1944, figure 2) and a hole in the dorsal cephalothorax (Schaller et al., 2004).

Opisthosomal injuries. Only one example of an opisthosomal injury was documented here: a ' $V$ ' shaped embayment on the left side of the Tachypleus tridentatus specimen (OUMNH.ZC.25121). A moveable spine has been removed and the two most posterior spines are shorter than those on the right side (Figure 3.1, 3.3-5). This injury is potentially similar to the opisthosomal injuries described, but not figured, in van der Meer Mohr (1941). The documented injury is more extreme than the Jell (1989, figure 1) specimen, as the Jell specimen did not have an embayment. The other previously documented opisthosomal injuries are broken posterior opisthosomal process on female Limulus polyphemus (Table 1) from mating (Brockmann, 1990; Shuster Jr, 2009).

Appendage injuries. No examples of abnormal appendages were illustrated here. However, injured cephalothoracic and thoracetronic appendages have been documented in previous studies (Table 1). Damaged pretarsus, apotele sections and processes of pushing legs are the most documented appendage injuries (van der Meer Mohr, 1935, 1941). Damaged and amputated walking legs and the loss of male pedipalps have also been noted (Bursey, 1977; Schaller et al., 2004, 2005; Duffy et al., 2006). Such injuries can persist through multiple moulting events (Itow et al., 1998a). Only one type of injured thoracetronic appendage is noted: injured book gills (Botton and Loveland, 1989). The examples noted here are detailed further in Table 1.

\section{Injuries to Fossil Taxa}

Exceptionally, three dimensionally (3D) preserved fossils assessed here allowed injuries (and potentially teratologies) to be identified, especially as healed injuries are easily distinguished from breaks created during fossilisation. The majority of specimens consisted only of the cephalothorax. As such, no telson and appendage abnormalities were documented, and only one opisthosomal injury was identified.

Mesolimulus walchi is superbly preserved in $3 \mathrm{D}$ in the Solnhofen Limestone (Jurassic) (Barthel et al., 1990). Two injured specimens from this deposit are documented (MCZ 106500 and MCZ 106372). One specimen had a 'W' shaped embayment on the left anterior cephalothorax, extending slightly into the most-anterior opisthosoma (Figure $4.1,4.3)$. The injury is cicatrised (has raised relief) and is therefore distinct from the breaks in the fossil. The other specimen had an asymmetric ' $V$ ' shaped embayment on the left anterior cephalothorax (Figure 4.2, 4.4).

Euproops danae specimens are most famously preserved in 3D within Mazon Creek fossil bed nodules (Upper Carboniferous) (Anderson, 1994; Babcock and Merriam, 2000). Among 430 specimens, three injured specimens were identified. Two had embayments that are considered injuries (FMNH.P 29193 and FMNH.PE 21972): a ' $V$ ' shaped embayment in the right anterior cephalothorax (Figure 5.5) and a 'W' shaped embayment in the anterior right cephalothorax (Figure 5.3-4). The third specimen (MCZ 4674) is unique: a series of parallel lineations or folds run across the entire left side, from the lateral ridge to the cephalothoracic margin (Figure 5.1-2). The lineations are closely spaced and follow the cephalothoracic shape. For comparison, consider the uninjured specimen (ROMIP 5827) illustrated in Figure 5.6.

\section{DISCUSSION}

Telson teratologies are among the most frequently recorded extant xiphosurid abnormalities (Figure 1 and Table 1). The long, slender morphology means that any abnormalities are obvious and as telsons conduct the high strain activity of overturning individuals, the telson spines are more commonly injured (Eagles, 1973; Shuster Jr and Sekiguchi, 2004). Botton and Loveland (1989) found that abnormal, missing, or damaged telsons were found among $19 \%$ of females and $32 \%$ of males in a sample of stranded Limulus polyphemus during the Delaware Bay spawning season. Shortened ("stubby") telsons were the most

FIGURE 1 (previous page). Examples of live Limulus polyphemus specimens with telson teratologies. (1,3) Double telson-divided at the opisthosomal joint. (2) Forked telson asymmetrically bifurcated. (4) Forked telson and an overdeveloped axial spine. (5) Damaged telson spine and spine-like overdevelopment of the posterior opisthosomal margin. $(1,2,4,5)$ Images in dorsal view. (3) Image in ventral view. No specimens were accessioned into collections. 

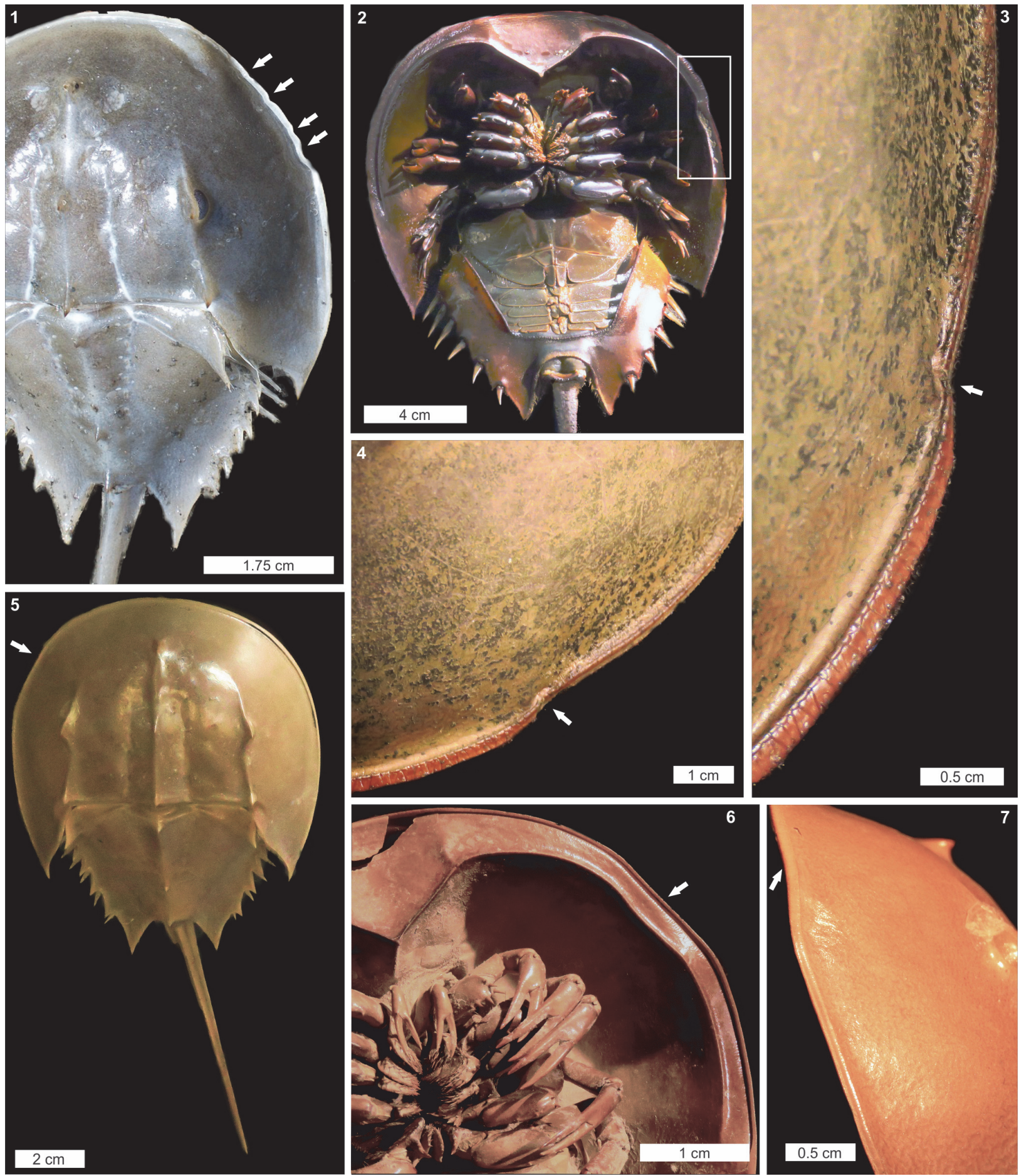

FIGURE 2. Examples of Limulus polyphemus with cephalothoracic injuries. (1) Four ' $U$ ' shaped embayments on right anterior cephalothorax (white arrows). (2-4) Small ' $U$ ' shaped embayment on left anterior cephalothorax. (2) Entire specimen. $(3,4)$ Close-ups of cephalothoracic buckling (white arrows). (5-7) Injury to left anterior cephalothorax (white arrows). $(1,4-5)$ images in dorsal view. $(2,5)$ Images in ventral view. $(3,7)$ Images in lateral view. No specimens were accessioned into collections. 

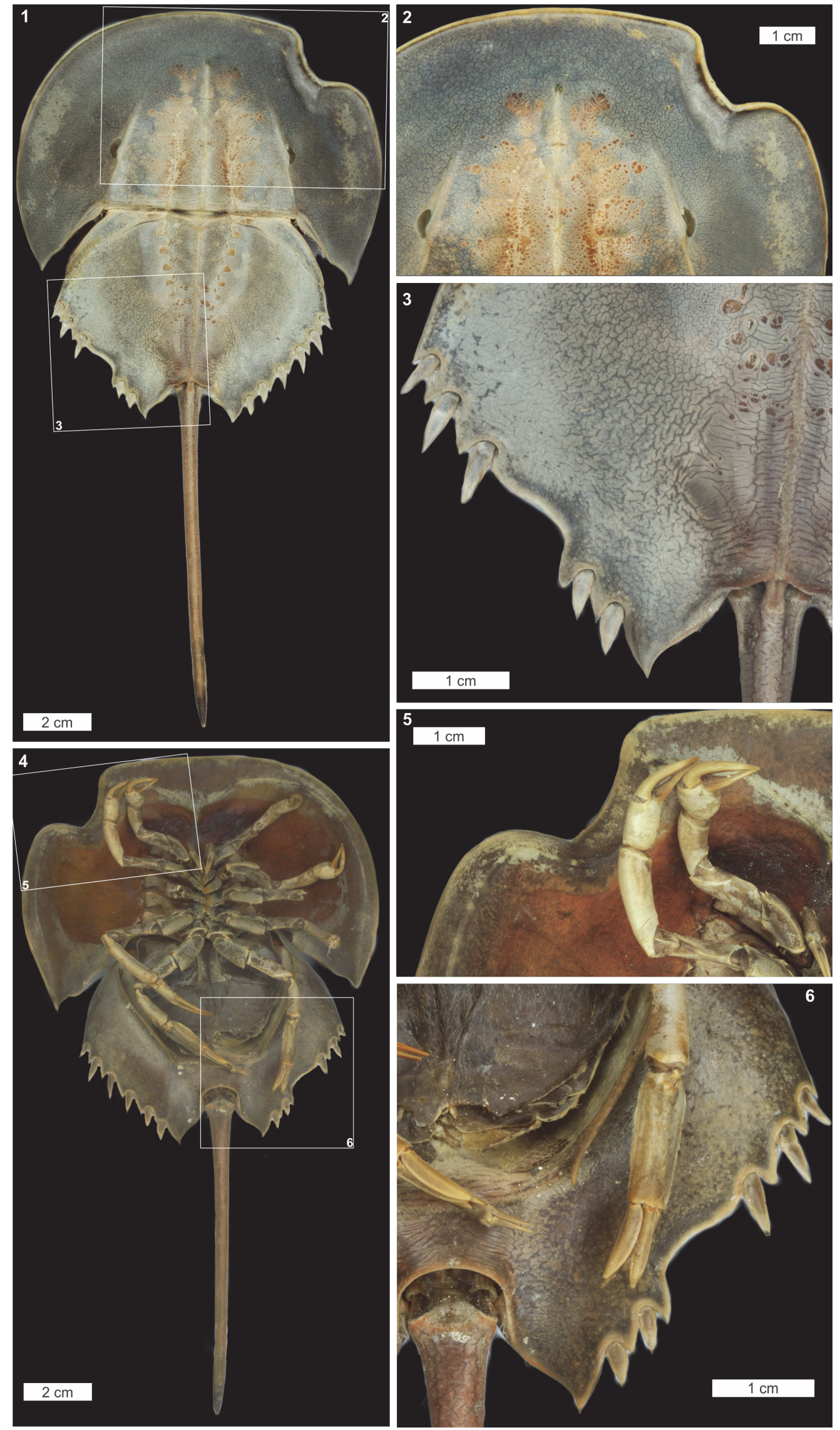
common $(15 \%$ of stranded females, $23 \%$ of stranded males), followed by missing, disarticulated, and curved telsons. Telson abnormalities were less abundant among non-stranded adult horseshoe crabs, suggesting that such abnormalities increased the risk of beach stranding during spawning. Gudger (1935) suggested that telson abnormalities probably occur during moulting and subsequent moult stages propagate spine abnormalities. We agree and therefore suggest that recently moulted individuals that are overturned may damage the telson righting themselves resulting in the development of teratologies. However, long-term studies using live specimens are needed to confirm this suggestion.

\section{Possible Source of Non-telson Abnormalities}

Extensive injuries to the Tachypleus tridentatus (Figure 3) and Limulus polyphemus (Jell 1989, figure 1) cephalothoracic and opisthosomal sections likely reflect predation. Jell (1989) suggested that such injuries reflect damage from rocks or storms. However, the likelihood that similar injuries are documented on different taxa challenges this idea. We suggest instead that a single predatory attack produced these extreme injuries.

Predatory attacks on Limulus polyphemus by large gulls frequently occur when the animals become stranded on intertidal beaches during spawning. Gulls usually target the ventral surface, especially the book gills (Botton and Loveland, 1989), but individuals can survive these attacks if they right themselves. Adult $L$. polyphemus are also preyed upon by American alligators (Alligator mississippiensis (Daudin, 1802)) and loggerhead turtles (Caretta caretta (Linnaeus, 1758)) (Reid and Bonde, 1990; Keinath, 2003); both can produce significant injuries on the cephalothorax and opisthosoma during unsuccessful predation events. Today, many carapace injuries in adult $L$. polyphemus are man-made mechanical injuries resulting from oyster dredges and other mobile fishing gear, motorized vehicles on beaches and intertidal sand flats, etc. (M. L. Botton, pers. observ.).

\section{Comparing Xiphosurid Injuries with Trilobite Injuries}

Trilobites are an extinct arthropod group adorned with biomineralised exoskeletons that arose during the early Cambrian (Series 2) (Bicknell and Paterson, 2018). Their exoskeletons were ideal protection against predators and recorded injuries from failed predation (Babcock, 2003; Zamora et al., 2011). As such, the record of potentially predatory injuries to Cambrian trilobites is extensively documented (see examples in Rudkin, 1979; Babcock, 1993, 2007; Pratt, 1998; Nedin, 1999; Fatka et al., 2008; Pates et al., 2017; Vinn, 2017; Bicknell and Paterson, 2018, table 1). Large Cambrian trilobite injuries are typically 'W', 'V', and ' $U$ ' shapes, and located on the cephalon, thorax, and pygidium (Babcock, 1993, 2003; Nedin, 1999). Most injuries are to thoracic and pygidial sections (Bicknell and Paterson, 2018) and are therefore not easily compared to the documented xiphosurid injuries. However, rare examples of cephalic injuries, specifically ' $U$ ' and ' $W$ ' shapes, are somewhat similar to xiphosurid cephalothoracic injuries, suggesting that they may have been incurred at similar developmental stages (Figure 6.1-4). Limulus polyphemus cephalothoracic injuries are likely incurred during a moulting event or the subsequent softshell stage when the exoskeleton is much softer and easier to damage (Brandt, 2002). Babcock (1993) suggested that injuries to trilobites reflect either predatory attacks on newly moulted or softshelled individuals, or moulting complications, as the exoskeleton is similarly easily damaged postmoult (e.g., Owen 1985; Babcock 1993; Brandt 2002; Zong et al. 2016; Bicknell and Paterson 2018). Given the similarity between the Recent xiphosurid cephalothoracic injuries and the cicatrised trilobite cephalic injuries, we suggest that, at least for the extreme examples documented here, cephalic injuries occurred during the soft-shelled stage. In this moult stage the exoskeletal strength of trilobites and xiphosurids would have been comparable and trilobites were "highly vulnerable to predators and accidents of tearing the new exoskeleton" (Brandt, 2002, p. 411). This comparison

FIGURE 3 (previous page). A Tachypleus tridentatus carcass with a cephalothoracic and opisthosomal injury (OUMNH.ZC.25121). (1, 4) Entire specimen with boxes around the injuries. $(2,5)$ Close-ups of large, buckled ' $U$ ' shaped embayment on anterior right cephalothorax. $(3,5)$ Close-ups of ' $V$ ' shaped injury to posterior left opisthosoma. Note missing fourth moveable spine. (4-5) Images in ventral view. Images courtesy of Oxford Museum of Natural History. 

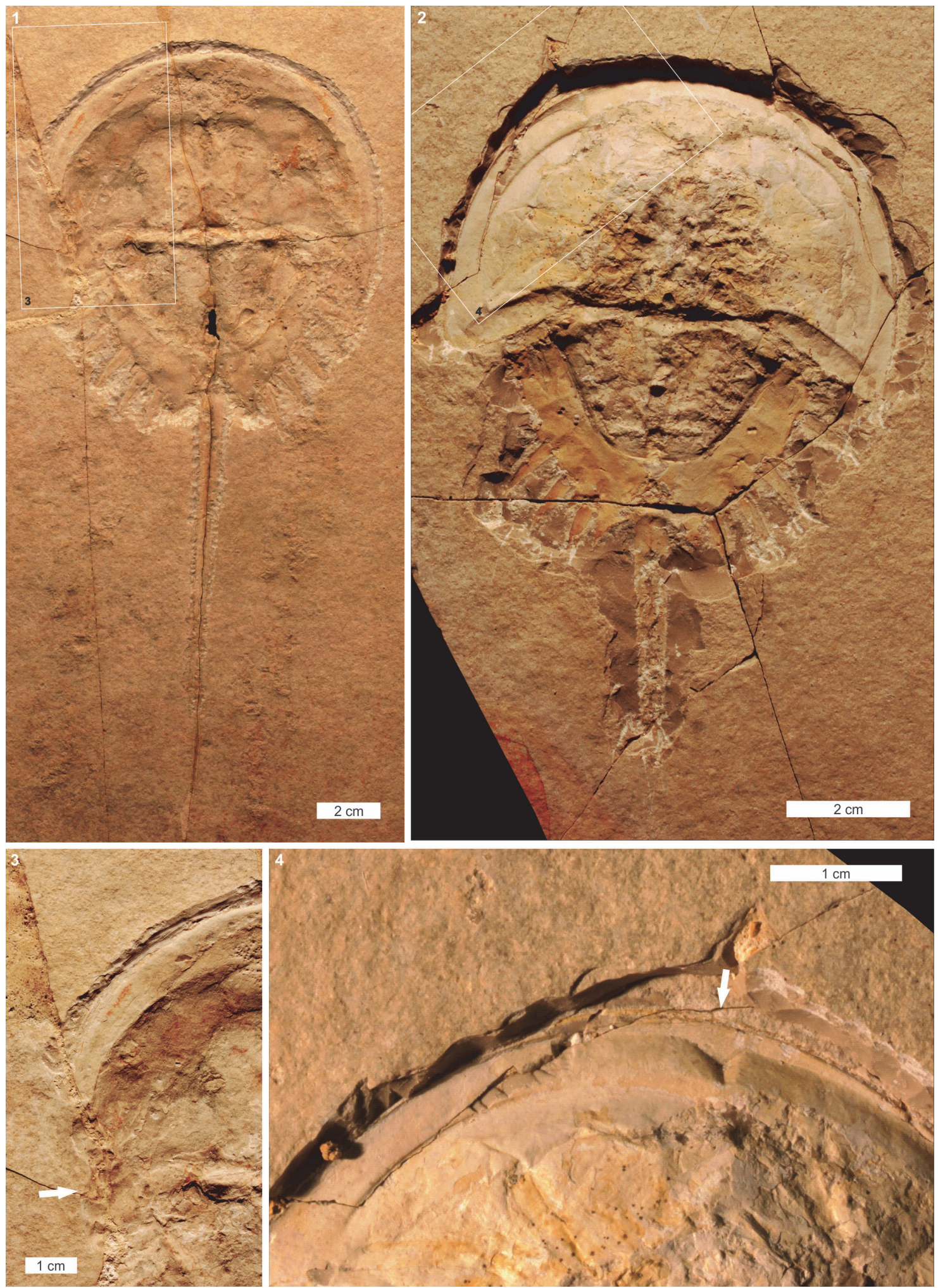

FIGURE 4. Cephalothorax injuries to Mesolimulus walchi (Jurassic, Solnhofen Limestone, Bavaria, Germany). (1, 3) MCZ 106372. Large 'W' shaped embayment (white arrow) on left cephalothorax. Injury extends into the opisthosoma. Box in (1) enlarged in (3). (2, 4) MCZ 106382. Prominent 'V' shaped injury (white arrow) to anterior left cephalothorax. Image credit: (1-4) Museum of Comparative Zoology, Harvard University 

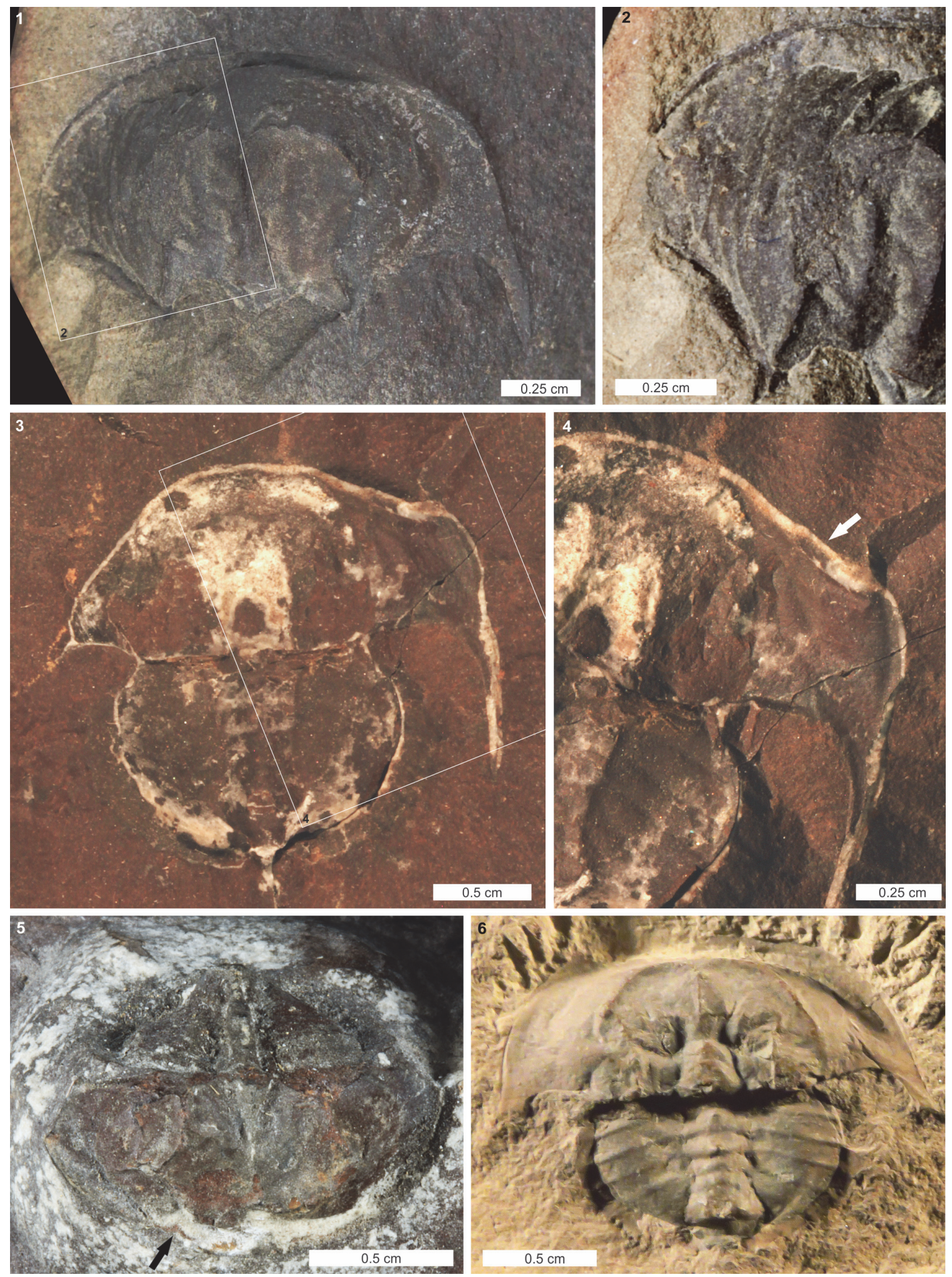

FIGURE 5. Cephalothorax injuries to Euproops danae (Francis Creek Shale, Will County, Illinois, USA, upper Carboniferous). (1, 2) FMNH.PE 21972. Parallel linear distortions to anterior left cephalothorax. (3, 4) MCZ 4674. 'W' shaped injury (white arrow) to right cephalothorax. (5) FMNH.P 29193. 'V' shaped injury (black arrow) on anterior right cephalothorax. (6): ROMIP5827. Complete, uninjured specimen for comparison. Image credit: (1) Mane Pritza, $(3,4)$ Museum of Comparative Zoology, Harvard University. 

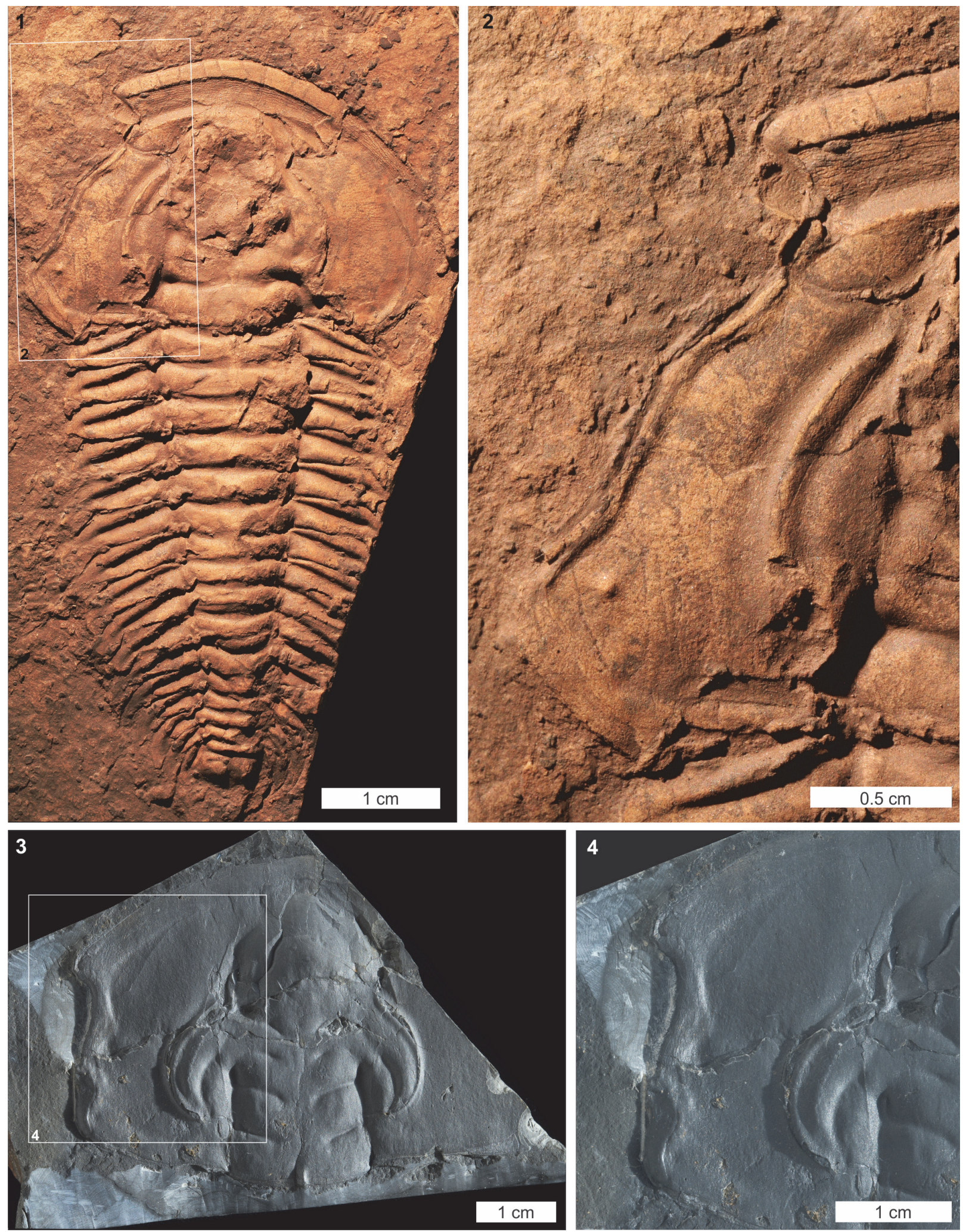

FIGURE 6. Cephalic injuries to Cambrian trilobites. $(1,2)$ Redlichia takooensis Lu, 1950 from the lower Cambrian (Series 2, Stage 4) Emu Bay Shale, Kangaroo Island, South Australia; SAM P48187. Cicatrised 'W' shaped injury to left cephalon. Injury was incurred during a recent moult. $(3,4)$ Olenellus thompsoni (Hall, 1859) from the Cambrian (Series 2, Stage 4) Kinzers Formation, Pennsylvania; USNM PAL 90809. Asymmetric, cicatrised 'U' shaped injury to left cephalon. Image credit: (1, 2) Originally figured in Bicknell and Paterson $(2018) ;(3,4)$ Frederick Cochard. 
is purely based on injury shape and the likelihood that the illustrated trilobite injuries were incurred during a soft-shelled stage and should not be extended to consider the predators that made the injuries. Although the broad mechanics of predation (e.g., crushing, breaking, striking) were likely similar, the predator groups are very different. Cambrian trilobite predators-Euarthropoda Sidneyia inexpectans, Wisangocaris barbarahardyae Jago et al., 2016, a Fuxianhuia-like arthropod, and perhaps other trilobites (Bruton 1981; Zhu et al., 2004; Daley et al., 2013; Jago et al., 2016; Zacaï et al., 2016; Bicknell and Paterson, 2018)—were very different to the predators of extant xiphosurids (see Walls et al., 2002). Nonetheless, these preliminary results highlight that such comparative research could be explored further.

\section{Fossil Xiphosurids}

Cephalothoracic sections of fossil xiphosurids are occasionally preserved well enough to examine for injuries, which augments the trace fossil evidence of predation noted in Diedrich (2011). The xiphosurids considered here have broadly similar cephalothoracic morphologies, and similar asymmetric ' $V$ ' and ' $W$ ' shaped injuries (Figures 4.1-4, 5.3-5). Furthermore, the only unusual non-marginal cephalothoracic features recorded here were on Euproops danae. The lineations along the cephalothorax suggest deformation immediately after a moulting event, perhaps from scratching. Alternatively, an equally plausible origin would be plastic deformation of a freshly moulted exoskeleton, where the lineations are subparallel folds due to compression. No examples of ' $U$ ' shaped injuries were identified on the extinct xiphosurid species, and we suggest that smaller ' $U$ ' shaped injuries, like those to Limulus polyphemus, may not be identifiable (Figure 2). This is because during healing, injuries become less angular and prominent, and are therefore harder to distinguish from taphonomic distortion.

The comparison of Recent and fossil xiphosurid injuries highlights two areas of future research. (1) The identification of potentially predatory injuries to xiphosurids in the Carboniferous suggests that analyses of injury frequencies through time are possible. Large museum collections of fossil Xiphosurida and spawning events of Recent species could therefore be examined for injury and teratology counts to highlight temporal changes to abnormalities. (2) The identification of Recent moulting abnormalities could inform the identity of fossil moulting complications, as xiphosurids are morphologically conservative (Avise et al., 1994; Rudkin and Young, 2009). If predatory injuries can be differentiated from such moult abnormalities, similar patterns may be identified for extinct groups such as the trilobites.

\section{CONCLUSION}

Our study of xiphosurid abnormalities concludes that (1) telson teratologies are the most commonly documented abnormality; (2) cephalothoracic and opisthosomal abnormalities are either seldom incurred or reported; (3) 'V' and 'W' shaped cephalothoracic injuries are preserved on fossil xiphosurids; and (4) cephalothoracic injuries to Recent xiphosurid can be used to explore the timing of cephalic injuries to Cambrian trilobites. The underdocumentation of extant and extinct xiphosurid abnormalities shows how this iconic group requires further attention and exploration, and has much potential for macroevolutionary studies.

\section{ACKNOWLEDGEMENTS}

This research was supported by funding from an Australian Postgraduate Award (to R.D.C.B.), a Keith and Dorothy Mackay Travelling Scholarship (to R.D.C.B.), Oxford-St Catherine's Brade-Natural Motion Scholarship (to S.P), and Santander Travel Award (to S.P). We thank F. Cochard, M. Pritza, the $M C Z$, and the OUMNH for providing images. We thank W. Watson and M. Owings for gathering live Limulus polyphemus specimens. We thank J. Cundiff (MCZ), M. Carnal (OUMNH), M. Akrami (ROM) and P. Mayer (FMNH) for help with collections. Finally, we thank the three anonymous referees and B. Błażejowski and the handling editor $\mathrm{M}$. Hyzny for their constructive reviews of the manuscript. 


\section{REFERENCES}

Anderson, L.I. 1994. Xiphosurans from the Westphalian D of the Radstock Basin, Somerset Coalfield, the South Wales Coalfield and Mazon Creek, Illinois. Proceedings of the Geologists' Association, 105:265-275. https://doi.org/10.1016/S0016-7878(08)80179-4

Avise, J.C., Nelson, W.S., and Sugita, H. 1994. A speciational history of "living fossils": molecular evolutionary patterns in horseshoe crabs. Evolution 48:1986-2001. https://doi.org/10.2307/ 2410522

Babcock, L.E. 1993. Trilobite malformations and the fossil record of behavioral asymmetry. Journal of Paleontology, 67:217-229. https://doi.org/10.1017/s0022336000032145

Babcock, L.E. and Merriam, D.F. 2000. Horseshoe crabs (Arthropoda: Xiphosurida) from the Pennsylvanian of Kansas and elsewhere. Transactions of the Kansas Academy of Science, 103:76-94. https://doi.org/10.2307/3627941

Babcock, L.E. Merriam, D.F., and West, R.R. 2000. Paleolimulus, an early limuline (Xiphosurida), from Pennsylvanian-Permian Lagerstätten of Kansas and taphonomic comparison with modern Limulus. Lethaia, 33:129-141. https://doi.org/10.1080/00241160025100017

Babcock, L.E. 2003. Trilobites in Paleozoic predator-prey systems, and their role in reorganization of early Paleozoic ecosystems, p. 55-92. In Kelley, P., Kowalewski, M., and Hansen, T.A. (eds), Predator-Prey Interactions in the Fossil Record. Plenum Publishers, New York. https://doi.org/10.1007/978-1-4615-0161-9_4

Babcock, L.E. 2007. Role of malformations in elucidating trilobite paleobiology: a historical synthesis, p. 3-19. In Mikulic, D.G., Landing, E., and Kluessendorf, J. (eds), Fabulous Fossils-300 Years of Worldwide Research on Trilobites. University of the State of New York, State Education Department, New York State Museum, New York.

Bang, F. and Bang, B. 1982. Pathology principles revealed by study of natural diseases of invertebrates. Progress in Clinical and Biological Research, 81:289-296.

Barthel, K.W., Swinburne N.H.M., and Conway Morris S. 1990. Solnhofen, a Study in Mesozoic Palaeontology. Cambridge University Press, Cambridge.

Bateson, W. 1894. Materials for the Study of Variation: Treated with Especial Regard to Discontinuity in the Origin of Species. Cambridge University Press, Cambridge.

Battelle, B-A. 2006. The eyes of Limulus polyphemus (Xiphosura, Chelicerata) and their afferent and efferent projections. Arthropod Structure \& Development, 35:261-274. https://doi.org/ 10.1016/j.asd.2006.07.002

Bicknell, R.D.C., Klinkhamer, A.J., Flavel, R.J., Wroe, S., and Paterson, J.R. 2018a. A 3D anatomical atlas of appendage musculature in the chelicerate arthropod Limulus polyphemus. PLOS ONE. https://doi.org/10.1371/journal.pone.0191400

Bicknell, R.D.C. and Paterson, J.R. 2018. Reappraising the early evidence of durophagy and drilling predation in the fossil record: implications for escalation and the Cambrian Explosion. Biological Reviews, 93:754-784. https://doi.org/10.1111/brv.12365

Bicknell, R.D.C., Paterson, J.R., Caron, J-B., and Skovsted, C.B. 2018b. The gnathobasic spine microstructure of Recent and Silurian chelicerates and the Cambrian artiopodan Sidneyia: Functional and evolutionary implications. Arthropod Structure and Development, 47:12-24. https://doi.org/10.1016/j.asd.2017.12.001

Błażejowski, B. 2015. The oldest species of the genus Limulus from the Late Jurassic of Poland, p. 3-14. In Carmichael, R.H., Botton, M.L., Shin, P.K.S., and Cheung, S.G. (eds.), Changing Global Perspectives on Horseshoe Crab Biology, Conservation and Management. Springer, Cham. https://doi.org/10.1007/978-3-319-19542-1_1

Botton, M.L. 1984. Diet and food preferences of the adult horseshoe crab Limulus polyphemus in Delaware Bay, New Jersey, USA. Marine Biology, 81:199-207. https://doi.org/10.1007/ bf00393118

Botton, M.L. and Loveland R.E. 1989. Reproductive risk: high mortality associated with spawning by horseshoe crabs (Limulus polyphemus) in Delaware Bay, USA. Marine Biology, 101:143151. https://doi.org/10.1007/bf00391453

Brandt, D.S. 2002. Ecydsial efficiency and evolutionary efficacy among marine arthropods: Implications for trilobite survivorship. Alcheringa, 26: 399-421. https://doi.org/10.1080/ 03115510208619264

Briggs, D.E.G., Siveter, D.J., Siveter, D.J., Sutton, M.D., Garwood, R.J., and Legg, D.A. 2012. Silurian horseshoe crab illuminates the evolution of arthropod limbs. Proceedings of the National Academy of Sciences, 109:15702-15705. https://doi.org/10.1073/pnas.1205875109 
Brockmann, H.J. 1990. Mating behavior of horseshoe crabs, Limulus polyphemus. Behaviour, 114:206-220. https://doi.org/10.1163/156853990x00121

Bruton, D.L. 1981. The arthropod Sidneyia inexpectans, Middle Cambrian, Burgess Shale, British Columbia. Philosophical Transactions of the Royal Society of London, Series B: Biological Sciences, 295:619-656. https://doi.org/10.1098/rstb.1981.0164

Bursey, C.R. 1977. Histological response to injury in the horseshoe crab, Limulus polyphemus. Canadian Journal of Zoology, 55:1158-1165. https://doi.org/10.1139/z77-150

Daley, A.C., Paterson, J.R., Edgecombe, G.D., García-Bellido, D.C., and Jago, J.B. 2013. New anatomical information on Anomalocaris from the Cambrian Emu Bay Shale of South Australia and a reassessment of its inferred predatory habits. Palaeontology, 56:971-990. https://doi.org/10.1111/pala.12029

Daudin, F. M. 1802. Histoire Naturelle Générale et Particulière des Reptiles. Paris De I'Imprimerie de F. Dufart.

Desmarest, A.-G. 1822. Les crustacés proprement dits, p. 66-154. In Levrault. F.-G. (eds.), Histoire naturelle des crustacés fossiles, sous les rapports zoologiques et geologiques. Paris. https://doi.org/10.5962/bhl.title.9102

Diedrich, C. 2011. Middle Triassic horseshoe crab reproduction on intertidal flats of Europe with evidence of predation by archosaurs. Biological Journal of the Linnean Society, 103:76-105. https://doi.org/10.1111/j.1095-8312.2011.01635.x

Duffy, E.E., Penn, D., Botton, M.L., Brockmann, H.J., and Loveland, R.E. 2006. Eye and clasper damage influence male mating tactics in the horseshoe crab, Limulus polyphemus. Journal of Ethology, 24:67-74. https://doi.org/10.1007/s10164-005-0163-5

Eagles, D.A. 1973. Tailspine movement and its motor control in Limulus polyphemus. Comparative Biochemistry and Physiology Part A: Physiology, 46A:391-407. https://doi.org/ 10.1016/0300-9629(73)90428-3

Fatka, O., Szabad, M., Budil, P., and Micka, V. 2008. Position of trilobites in Cambrian ecosystem: preliminary remarks from the Barrandian region (Czechia), p. 117-122. In Rábano, I., Gozalo, R., and García-Bellido, D.C. (eds), Advances in Trilobite Research. Madrid Instituto Geológico y Minero de Espãna, Madrid.

Gerhart, S.D. 2007. A review of the biology and management of horseshoe crabs, with emphasis on Florida populations. Fish and Wildlife Research Institute Technical Report TR-12. ii + 24 p.

Gravier, M.C. 1930. Sur les malformations d l'appendice caudel chez les Limules. Bulletin du Museum national d'histoire naturelle, 2:89-91.

Gudger, E.W. 1935. Horseshoe crabs with forked tails. Bulletin of the New York Zoological Society, 38:170-173.

Hall, J. 1859. Trilobites of the shales of the Hudson River Group. 12th Annual Report of the New York Cabinet for Natural History, Albany, New York: 59-62.

Hu, S., Zhang, Q., Feldmann, R.M., Benton, M.J., Schweitzer, C.E., Huang, J., Wen, W., Zhou, C., Xie, T., Lü, T., and Hong, S. 2017. Exceptional appendage and soft-tissue preservation in a Middle Triassic horseshoe crab from SW China. Scientific Reports, 7:14112. https://doi.org/ 10.1038/s41598-017-13319-x

Itow, T. 1985. The induction of malformed embryos by inhibition of cell proliferation in the horseshoe crab, Tachypleus tridentatus. Acta Embryologiae et Morphologiae Experimentalis, 5:177-193.

Itow, T. 1986. Inhibitors of DNA synthesis change the differentiation of body segments and increase the segment number in horseshoe crab embryos (Chelicerata, Arthropoda). Roux's Archives of Developmental Biology \& Philosophy, 195:323-333. https://doi.org/10.1007/ bf00376065

Itow, T., Igarashi, T., Botton, M.L., and Loveland, R.E. 1998a. Heavy metals inhibit limb regeneration in horseshoe crab larvae. Archives of Environmental Contamination and Toxicology 35:457-463.

Itow, T., Loveland, R.E., and Botton, M.L. 1998b. Developmental abnormalities in horseshoe crab embryos caused by exposure to heavy metals. Archives of Environmental Contamination and Toxicology, 35:33-40. https://doi.org/10.1007/s002449900345

Jago, J.B., García-Bellido, D.C., and Gehling, J.G. 2016. An early Cambrian chelicerate from the Emu Bay Shale, South Australia. Palaeontology, 59:549-562. https://doi.org/10.1111/ pala.12243

Jell, P.A. 1989. Some aberrant exoskeletons from fossil and living arthropods. Memoirs of the Queensland Museum, 27:491-498. 
Kaplan, R., Li, S.S., and Kehoe, J.M. 1977. Molecular characterization of limulin, a sialic acid binding lectin from the hemolymph of the horseshoe crab, Limulus polyphemus. Biochemistry, 16: 4297-4303. https://doi.org/10.1021/bi00638a026

Keinath, J.A. 2003. Predation of horseshoe crabs by loggerhead turtles, p. 152-153. In Shuster, C.N. Jr, Barlow, R.B., and Brockmannm H.J. (eds.), The American Horseshoe Crab. Harvard Press, Cambridge.

Kin, A. and Błażejowski, B. 2014. The horseshoe crab of the genus Limulus: living fossil or stabilomorph? PLoS One 9: e108036. https://doi.org/10.1371/journal.pone.0108036

Lamsdell, J.C. 2013. Revised systematics of Palaeozoic 'horseshoe crabs' and the myth of monophyletic Xiphosura. Zoological Journal of the Linnean Society, 167:1-27. https://doi.org/ 10.1111/j.1096-3642.2012.00874.x

Lankester, E.R. 1881. Limulus an Arachnid. Quarterly Journal of Microscopical Science, 23:504649.

Leach, W.E. 1819. Entomostraca. Dictionaire des Science Naturelles. Levrault and Schoell, Paris.

Leibovitz, L. and Lewbart, G. 2003. Diseases and symbionts: vulnerability despite tough shells, p. 245-275. In Shuster, C.N. Jr, Barlow, R.B., and Brockmann, H.J. (eds.), The American Horseshoe Crab, Harvard Press, Cambridge.

Leighton, L.R. 2011. Analyzing predation from the Dawn of the Phanerozoic, p. 73-109. In Laflamme, M., Schiffbauer, J.D., and Dornbos, S.Q. (eds.), Quantifying the Evolution of Early Life. Springer, Dordrecht. https://doi.org/10.1007/978-94-007-0680-4_4

Linnaeus, C. 1758. Systema naturæ per regna tria naturæ, secundum classes, ordines, genera, species, cum characteribus, differentiis, synonymis, locis. Laurentius Salvius, Holmia. https:/ /doi.org/10.5962/bhl.title.559

Lu, Y. 1950. On the genus Redlichia with description of its new species. Geological Review 15: 157-170. (In Chinese)

Meek, F.B. and Worthen, A.H. 1865. Notice of some new types of organic remains, from the Coal Measures of Illinois. Proceedings of the Academy of Natural Sciences of Philadelphia 17: 4148.

Müller, O.F. 1785. Entomostraca seu Insecta Testacea, quae in aquis Daniae et Norvegiae reperit, descripsit et iconibus illustravit. Symtibus Bibliopolii J.G. Mülleriani, Müller, O. F. Lipsiae et Havniae: Leipzig and Copenhagen.

Nedin, C. 1999. Anomalocaris predation on nonmineralized and mineralized trilobites. Geology 27:987-990. https://doi.org/10.1130/0091-7613(1999)027<0987:APONAM>2.3.CO;2

Osburn, R.C. 1911. An unusual horseshoe crab. Bulletin of the New York Zoological Society, 48:808.

Owen, A.W. 1985. Trilobite abnormalities. Transactions of the Royal Society of Edinburgh: Earth Sciences, 76:255-272. https://doi.org/10.1017/s0263593300010488

Owen, R. 1872. On the anatomy of the American King-crab (Limulus polyphemus, Latr.). Transactions of the Linnean Society of London, 28:459-506. https://doi.org/10.5962/ bhl.title. 11275

Packard, A.S. 1870. The development of Limulus polyphemus. Memoirs of the Boston Society of Natural History, 2:155-202.

Pates, S., Bicknell, R.D.C., Daley, A.C., and Zamora, S. 2017. Quantitative analysis of repaired and unrepaired damage to trilobites from the Cambrian (Stage 4, Drumian) Iberian Chains, NE Spain. Palaios, 32:750-761. https://doi.org/10.2110/palo.2017.055

Poschmann, M., Schoenemann, B., and McCoy, V.E. 2016. Telltale eyes: the lateral visual systems of Rhenish Lower Devonian eurypterids (Arthropoda, Chelicerata) and their palaeobiological implications. Palaeontology, 59:295-304. https://doi.org/10.1111/pala.12228

Reid, J.P. and Bonde, R.K. 1990. Alligator mississippiensis (American alligator) diet. Herpetological Reviews, 21:59.

Rudkin, D.M. 1979. Healed injuries in Ogygopsis klotzi (Trilobita) from the Middle Cambrian of British Columbia. Royal Ontario Museum, Life Sciences Occasional Paper, 32:1-8.

Rudkin, D.M. and Young, G. 2009. Horseshoe crabs-an ancient ancestry revealed, p. 25-44. In Tanacredi, J.T., Botton, M.L., and Smith, D.R. (eds.), Biology and Conservation of Horseshoe Crabs. Springer, Boston. https://doi.org/10.1007/978-0-387-89959-6_2

Schaller, S.Y., Thayer, P. and Hanson, S. 2004. Maine horseshoe crab (Limulus polyphemus) spawning surveys, 2003. Report to Maine Department of Marine Resources. Buxton, ME: Bar Mills Ecological. 
Schaller, S.Y., Thayer, P., Hanson, S., LaTulippe, S., and Solet, E. 2005. Maine horseshoe crab (Limulus polyphemus) spawning surveys, 2004. Report to Maine Department of Marine Resources. Buxton, ME: Bar Mills Ecological.

Sekiguchi, K. and Sugita, H. 1980. Systematics and hybridization in the four living species of horseshoe crabs. Evolution 34:712-718. https://doi.org/10.2307/2408006

Selden, P.A. 1981. Functional morphology of the prosoma of Baltoeurypterus tetragonophthalmus (Fischer) (Chelicerata: Eurypterida). Transactions of the Royal Society of Edinburgh: Earth Sciences, 72:9-48. https://doi.org/10.1017/s0263593300003217

Shultz, J.W. 2001. Gross muscular anatomy of Limulus polyphemus (Xiphosura, Chelicerata) and its bearing on evolution in the Arachnida. Journal of Arachnology, 29:283-303. https:// doi.org/10.1636/0161-8202(2001)029[0283:gmaolp]2.0.co;2

Shuster, Jr. C.N. 1982. A pictorial review of the natural history and ecology of the horseshoe crab Limulus polyphemus, with reference to other Limulidae. Progress in Clinical and Biological Research, 81:1-52.

Shuster, Jr. C.N. 2009. Public participation in studies on horseshoe crab populations, p. 585-594. In Tanacredi, J.T., Botton, M.L., and Smith, D.R. (eds.), Biology and Conservation of Horseshoe Crabs. Springer, Dordrecht. https://doi.org/10.1007/978-0-387-89959-6_38

Shuster, Jr. C.N. and Sekiguchi. K. 2004. Growing up takes about ten years and eighteen stages, p. 103-132. In Shuster, C.N. Jr., Barlow, R.B., and Brockmann, H.J. (eds.), The American Horseshoe Crab. Harvard Press, Cambridge.

Smith, S.A. and Berkson, J. 2005. Laboratory culture and maintenance of the horseshoe crab (Limulus polyphemus). Lab Animal, 34:27-34. https://doi.org/10.1038/laban0705-27

Sokoloff, A. 1978. Observations on populations of the horseshoe crab Limulus (= Xiphosura) polyphemus. Researches on Population Ecology, 19:222-236.

van der Hoeven, J. 1838. Recherches sur I'histoire naturelle et l'anatomie des limules. Luchtmans, Leyden. https://doi.org/10.5962/bhl.title.120127

van der Meer Mohr, J.C. 1935. Sur quelques malformations chez la limule, Tachypleus gigas. Miscellanea Zoologica Sumatrana, 87:1-3.

van der Meer Mohr, J.C. 1941. A note on two species of Malaysian king-crabs (Xiphosura). Treubia, 18:201-205.

Van Roy, P., Orr, P.J., Botting, J.P., Muir, L.A., Vinther, J., Lefebvre, B., El Hariri, K., and Briggs, D.E.G. 2010. Ordovician faunas of Burgess Shale type. Nature, 465:215-218. https://doi.org/ 10.1038/nature09038

Walcott, C.D. 1911. Cambrian geology and paleontology II. Middle Cambrian Merostomata. Smithsonian Miscellaneous Collections 57, 17-40.

Walls, E.A., Berkson, J., and Smith, S.A. 2002. The horseshoe crab, Limulus polyphemus: 200 million years of existence, 100 years of study. Reviews in Fisheries Science, 10:39-73. https:/ /doi.org/10.1080/20026491051677

Yang, J., Ortega-Hernández, J., Legg, D.A., Lan, T., Hou, J-b., and Zhang, X-g. 2018. Early Cambrian fuxianhuiids from China reveal origin of the gnathobasic protopodite in euarthropods. Nature Communications, 9:470. https://doi.org/10.1038/s41467-017-02754-z

Zacaï, A., Vannier, J., and Lerosey-Aubril, R. 2016. Reconstructing the diet of a 505-million-yearold arthropod: Sidneyia inexpectans from the Burgess Shale fauna. Arthropod Structure \& Development, 45:200-220. https://doi.org/10.1016/j.asd.2015.09.003

Zamora, S., Mayoral, E., Esteve, J., Gámez-Vintaned, J.A., and Santos, A. 2011. Exoskeletal abnormalities in paradoxidid trilobites from the Cambrian of Spain, and a new type of bite trace. Bulletin of Geosciences, 86:665-673. https://doi.org/10.3140/bull.geosci.1275

Zhang, Q.Y., Hu, S.X., Zhou, C.Y., Lü, T., and Bai, J.K. 2009. First occurrence of horseshoe crab (Arthropoda) fossils from China. Progress in Natural Science 19:1090-1093.

Zhu, M.Y., Vannier, J., Iten, H., and Zhao, Y.L. 2004. Direct evidence for predation on trilobites in the Cambrian. Proceedings of the Royal Society of London B: Biological Sciences, 271:S277-S280. https://doi.org/10.1098/rsbl.2004.0194

Zong, R.-W., Fan, R.-Y., and Gong, Y.-M. 2016. Seven 365-million-year-old trilobites moulting within a nautiloid conch. Scientific Reports, 6:34914. https://doi.org/10.1038/srep34914 